\title{
Policy Support Within a Target Group: The Case of School Desegregation
}

D. S. Gatlin

M. W. Giles

Everett F. Cataldo

Cleveland State University, e.cataldo@csuohio.edu

Follow this and additional works at: https://engagedscholarship.csuohio.edu/clpolsci_facpub

How does access to this work benefit you? Let us know!

Publisher's Statement

Copyright 1978 Cambridge University Press. Available on publisher's site at

http://www.jstor.org/stable/1955116.

\section{Original Citation}

Gatlin, D.S., M.W. Giles, and Everett F. Cataldo. 1978. "Policy Support Within a Target Group: The Case of School Desegregation." American Political Science Review 72: 985-995.

\section{Repository Citation}

Gatlin, D. S.; Giles, M. W.; and Cataldo, Everett F., "Policy Support Within a Target Group: The Case of School Desegregation" (1978). Political Science Faculty Publications. 1.

https://engagedscholarship.csuohio.edu/clpolsci_facpub/1

This Article is brought to you for free and open access by the Political Science Department at EngagedScholarship@CSU. It has been accepted for inclusion in Political Science Faculty Publications by an authorized administrator of EngagedScholarship@CSU. For more information, please contact library.es@csuohio.edu. 


\title{
Policy Support within a Target Group: The Case of School Desegregation*
}

\author{
Douglas S. Gatlin and Micheal W. Giles \\ Florida Atlantic University \\ EvERETT F. CATALDo \\ Cleveland State University
}

\begin{abstract}
This study empirically tests three theoretical approaches to explaining specific support for a policy output among members of its target group. The utilitarian model posits support as a function of objective costs and benefits to the individual stemming directly from the policy. The attitudinal model relates specific support to diffuse predispositions rooted in socialization. The perceptual model holds that specific support derives from beliefs about the character of the political decision process by which the policy was formulated. Tests of these three approaches are based on survey data on specific support for school district desegregation plans among a large sample of black and white parents of public school children in Florida. In both subsamples, the utilitarian approach explained very little of the variance in support, but the attitudinal and perceptual models were corroborated. Implications of these findings are drawn for desegregation policy making and for public policy theory.
\end{abstract}

The implementation of school desegregation policies has sparked bitter and sometimes violent reactions from white parents. Protest marches, boycotts, petitions and in some instances riots and bombings have occurred, and many whites have withdrawn their children from the affected schools. In some districts the white exodus has been large enough to result in resegregation as the public schools became allor nearly all-black (Beckler, 1971, p. 2; Graglia, 1976, passim; Nevin and Bills, 1976, Ch. 2). Nevertheless, behavioral compliance has been the characteristic response of whites to the implementation of desegregation. The overwhelming majority of southern white children now attend desegregated public schools (Farley and Taeuber, 1974; Giles, 1975). Clearly, however, behavioral compliance with a public policy does not necessarily signify subjective support for it. Indeed, surveys and polls report that a large majority of southern whites oppose governmental action to desegregate the schools

\footnotetext{
*The research reported herein was conducted under a grant from the National Science Foundation, Division of Research Applied to National Needs, GI34955. The opinions expressed, however, are those of the authors and shoult not be construed as representing the opinions or policy of any agency of the United States government. The authors are grateful to Deborah Athos, Emilie Rappoport, and Wen-Fu P. Shih, our research associates, for their invaluable assistance at many stages of the project.
}

(Greeley and Sheatsley, 1971; The Gallup Opinion Index, 1973; Knapp and Alston, 1972-73).

Given widespread behavioral compliance with a public policy, is subjective nonsupport sufficiently important to deserve analysis by political scientists? Evidence on popular reactions to school desegregation points to an affirmative answer. First, current pressures in Congress to curtail school busing are clearly reactions from those affected by desegregation and who oppose it. Second, Miller and Citrin (1974) suggest that opposition to specific policies may be a source of recent increases in political cynicism among the American public, and report that those opposed to governmental action to desegregate the schools are more often cynics than those accepting action. Third, opposition to desegregation appears to have a "spillover effect" in undermining voter support for increased school funding (Giles, et al., 1976). Finally, parental hostility to desegregation often appears to be transferred to children, leading to disciplinary and educational problems within the schools (St. John, 1975, pp. 64-65 and 89-91). None of this evidence challenges the moral validity of school desegregation in an egalitarian society. However, it reveals that, behavioral compliance notwithstanding, subjective nonsupport may have farreaching ramifications within the policy process and, therefore, that it merits scholarly attention. 
The purpose of this study is to set forth several possible determinants of subjective support for public policies, and to test them empirically respecting governmental actions to desegregate the schools. In this study, desegregation policy will refer to local school district programs to achieve racially unitary school systems. For, while federal action mandates district officials to carry out desegregation, it is normally the locally designed program that conditions the behavior of the public so as to make desegregation a reality. Second, the target group is here defined as the parents or guardians of children attending public schools in districts that have undergone desegregation. Thus, the dependent variable is subjective support among parents for desegregation programs within the school districts where they reside.

\section{Determinants of Subjective Support}

The literature suggests a number of theoretically disparate hypotheses about factors that may affect policy support among members of a target group. In the interests of theoretical clarity, we shall classify them below according to the types of independent variables they employ: (1) objective costs imposed by the policy, (2) long-run attitudes rooted in socialization processes, and (3) short-run perceptions of the political process by which the policy was adopted. While most scholars have restricted themselves to a single approach, all three approaches will be considered here as avenues to explaining parents' support for local desegregation policies.

Policy Costs. Current utility theories of individual decision making portray citizens as rational actors who respond to political stimuli according to their personal costs and benefits; as the ratio of costs to benefits increases, responses become increasingly negative (Downs, 1957, pp. 3-11; Salem and Bowers, 1972; Stover and Brown, 1975). We may infer that as the costs of desegregation policies to parents increases, the support of parents will decline. Utility theories normally assume that people's subjective evaluations of their costs and benefits affect their reactions. However, for the purpose of studying policy impacts, it is more pertinent to understand how support may be affected by variations in the objective demands that a policy places upon them. Only in this way can we be sure of distinguishing genuine policy impacts from attitudinal orientations as determinants of support.

School district decision makers across the nation have a common repertoire of three policy elements which they apply to the target group to achieve school desegregation. One is the establishment of black/white attendance ratios for each district school. These ratios may vary somewhat to allow for differences in the percent of blacks in the school-age population by grade levels and the physical capacity of the schools. Second, it is normally necessary to bus many children to overcome residential segregation and to implement racial quotas for individual schools. Third, the spatial dispersion of the schools will require that bused children be transported varying distances from home to school. Therefore, the working hypothesis is that as children experience increasing demands from these desegregation plan elements, their parents' support for the local policy will diminish.

Diffuse Attitudes. An extensive literature on political socialization stresses the importance of diffuse attitudes, often acquired early in life, as determinants of both general and specific support for political objects. (See, for example, Easton, 1965, Chs. 16-20; Almond and Verba, 1963, Chs. 7-9; Dennis, 1973). Three such attitudes will be considered here: racial prejudice, orientations toward the social goals of school integration, and also toward the legitimacy of governmental action to desegregate the schools.

(1) Opposition to school integration among whites is most commonly attributed to racial prejudice (Tumin, et al., 1958; cf. Kelley, 1974). For highly prejudiced whites, desegregation may be a symbolic deprivation even if their children are objectively unaffected by local implementation procedures. Conversely, parents with egalitarian racial attitudes may support the policy even if it drastically alters the conditions of their children's schooling.

(2) A "great debate" continues to be heard concerning the possible effects of desegregation on educational processes (Coleman, 1967; Pettigrew, 1971; St. John, 1975). Prejudice aside, parents' misgivings about the impact of desegregation on school discipline, racial harmony or conflict, and scholastic quality may engender negative reactions to implementation policies. Other parents may be so committed to desegregation as a matter of equal rights and social justice as to submerge any such doubts. In brief, attitudes toward integrating the schools as a social goal may influence parents' willingness to support local policy.

(3) People's general predispositions toward the legitimacy of governmental action in a policy field are said to influence their acceptance of related, specific outputs (Easton, 1965, Ch. 19; Johnson, 1967, Ch. 2). Indeed, Easton suggests $(1965$, p. 278$)$ that even in the 
face of high objective policy costs, support for a policy may be sustained by a strong sense of the moral validity of official action. The hypothesis is that parents' acceptance of local desegregation policies varies directly with their sense of the legitimacy of governmental action to desegregate the schools.

Perceptions of Efficacy and Elite Attitudes. Two major themes recur in the literature concerning the roles of citizens and elites in the policy-making process. One seems rooted in the elitist theory of democracy while the other reflects participatory or populistic theories of citizenship.

Elitist theory has portrayed the mass public as generally ambivalent in its views toward specific policies, except perhaps when the latter directly impinge on personal interests. Hence, the theory stresses the capacity of political leaders to influence mass opinions on policy issues (Dahl, 1961, pp. 164-65 and 264-67; Dye and Zeigler, 1970, pp. 154-61). Some empirical research casts doubt on leaders' ability to shape mass views of specific policies (Lane and Sears, 1965, Ch. 5; Sears and Whitney, 1973). Nevertheless, the assumption of elite influence has pervaded both academic and official publications dealing with school integration (Chesler, et al., 1969; Crain, 1974, p. vi; St. John, 1975, p. 124). In brief, these publications argue that a unified front in favor of integration among local school officials will promote community acquiescence and discourage resistance to desegregation. Therefore, we may hypothesize that parents who perceive their district officials as unified in favor of integration will tend to support local policies, while those who perceive a consensus against integration among local officials will be nonsupportive.

In contrast to the elite influence hypothesis, the populistic view emphasizes the importance that citizens may attach to their active capacity to contribute to the policy-making process. The ability to "have a voice" in the formulation of public policy is said to be valued not only as means of protecting individual interests but also an affirmation of personal autonomy and efficacy (Pateman, 1970, Ch. 2; Thompson, 1970, pp. 13-22). Moreover, empirical evidence from Almond and Verba's five-nation study $(1963$, pp. 240-53) indicates that the belief that one can participate effectively in the political system heightens satisfaction with its specific performance. In a similar vein, current administrative theory holds that the public's participation in policy formation contributes both to support for the policy and to the achievement of its goals (Rourke, 1976, pp.
147-49). Therefore, we hypothesize that parents' willingness to accept local desegregation policy varies directly with their sense of efficacy in its formulation.

\section{The Data}

Data for this study are drawn from a survey of white and black parents of public elementary and secondary school children in seven Florida school districts. Florida has been affected by school desegregation to an extent not found in any other state. Every school district in Florida has experienced desegregation, usually involving extensive busing and mandatory racial balances in all public schools. Moreover, since all school districts in Florida are county-wide, white parents have no escape from desegregation save the private schools. Predictably, political leaders' expressed opposition to desegregation has drawn widespread acclaim throughout Florida. In the 1972 Democratic presidential primary, George Wallace's denunciation of forced integration by federal officials almost certainly helped to gain him a plurality of the vote in every one of the state's 67 counties. In a "straw ballot" in the same election, a majority of voters in every county signified their opposition to busing for desegregation. Also during the 1972 campaign, Richard Nixon advocated "an immediate stop to further new [sic] busing orders by the Federal courts" and "the right of a community to maintain neighborhood schools" (Congressional Quarterly Almanac, 1972 , p. 51-A). As desegregation took effect in Florida, public protest meetings were held, petitions against desegregation were circulated, sporadic violence broke out and private school enrollments mounted. Nevertheless, the great majority of white parents continued to send their children to public schools. Therefore, Florida presents almost an ideal setting for research on subjective support and non-support for desegregation within a context of maximum application of judicial standards opposed by most whites and their elected leaders.

The 7 study districts were chosen from the 67 in the state to assure variation in urbanization, geographical location, and the percentage of black children in the school-age population. Four of the districts are among the 100 largest in the nation: Dade (6th), Duval (20th), Palm Beach (49th) and Escambia (82nd). Two districts, Lee and Leon, are smaller sized SMSAs, while Manatee is nonmetropolitan. The black population in the districts varies from 19 percent to 33 percent. At the time of the survey, desegregation plans had been implemented in all 7 study districts. 
children in these districts was gleaned from official school records, and a total of 2109 white and 1049 black parents were interviewed in the winter and spring of 1973. Thus, all interviewees had had direct experience with desegregation in their school districts. Interview items referred to a single "cue child" in the respondent's family who had been identified from school records and who was referred to by name in the course of the interview. All interviews were conducted in the parent's home by a professional interviewer of the respondent's race.

Respondents' summary opinions of desegregation policy in their school districts were obtained through the question, "In general, how do you feel about the way that school desegregation has been handled around here"? with responses precoded on a five-point scale from "approve strongly" to "disapprove strongly." Responses to this question are presented in Table 1. These percentages cannot be extrapolated to other populations but they reveal sufficient variations in response within both racial groups to permit analysis of some sources of parental support for desegregation policy in their districts.

Table 1. "In General, How Do You Feel About the Way Desegregation Has Been Handled Around Here?"1

\begin{tabular}{lcc}
\hline \hline & $\begin{array}{c}\text { White } \\
\text { Parents }\end{array}$ & $\begin{array}{c}\text { Black } \\
\text { Parents }\end{array}$ \\
\hline Approve strongly & $2.2 \%$ & $9.3 \%$ \\
Approve & 21.6 & 46.3 \\
Neither approve nor disapprove & 15.8 & 17.7 \\
Disapprove & 29.9 & 18.4 \\
Disapprove strongly & 30.3 & 8.0 \\
Don't know; not sure & .2 & .3 \\
& $100.0 \%$ & $100.0 \%$ \\
\hline Number of respondents & 2109 & 1049 \\
Mean (5-point scale) & 2.29 & 3.31 \\
Standard deviation & 1.20 & 1.17 \\
\hline
\end{tabular}

${ }^{1}$ Immediately following this item, parents were asked the open-ended question, "why do you say that?" Up to three verbatim responses were content analyzed. Approximately two-thirds of each subsample answered in terms of local school district conditions, e.g., busing, attendance zones, the effect of desegregation on education and discipline, and local officials' actions. Less than one-third of all responses alluded to general feelings about school integration. Therefore, the responses in Table 1 are very largely addressed to specific conditions of desegregation rather than casual or diffuse attitudes toward integration.

Also, the responses in Table 1 seem to signify not mere passive acquiescence or disaffection, but rather
The percent black enrollment in all public schools in the seven study districts was obtained from official school records and was match-merged with our interview data to permit analysis of parents' responses according to the black/white ratio in the school attended by their child. Interviewees reported whether or not their children were bused to school. Those whose children were bused were also asked to estimate the distance in miles one way. According to policies in all districts, children who are not bused reside within two miles of their public school.

Twelve interview items were designed to measure respondents' racial prejudice, their attitudes toward the social goals of school integration and toward the legitimacy of government action. The prejudice items were omitted in interviews with black respondents. Factor analysis of the attitudinal items produced a three-factor solution for white respondents and two-factor solution for black respondents. ${ }^{2}$ The pattern of item correlations with the dimensions was consistent with the hypothesized content of the items. School integration, legitimacy and, for whites, racial prejudice scores were computed for respondents by summing their responses to items loading heavily on the respective factors.

To measure perceptions of local elite consensus, respondents were asked how the "superintendent of schools" and "most of the school board" in their counties felt about school integration. Responses to these questions were precoded (1) "for integration" and (2) "against integration," and were summed. ${ }^{3}$ Finally,

support or nonsupport in a more positive sense. As responses in Table 1 become increasingly unfavorable, respondents were more likely to report having engaged in protest activities. Also, those at the "strong" ends of the scale were more likely to be "opinion leaders" concerning desegregation.

${ }^{2} \mathrm{~A}$ report of the factor analysis will be mailed to interested readers, upon request.

${ }^{3}$ There was considerable variation among the seven study districts in the extent to which school officials publicly supported desegregation. The authors compiled a list of 13 supportive activities that officials might undertake-including, for example, publicly stating their intention to implement school desegregation and calling for community support for it. Several expert informants in each district indicated which measures had been carried out locally and which had not. In one district, all 13 (and more) had been undertaken by school officials. In another, only 7 had occurred, while the remaining districts displayed variations between these extremes. Hence, survey respondents had been exposed to a range of differences in leadership activities sufficient to permit meaningful 
parents' sense of efficacy respecting local desegregation policy was assessed by the question, "how much influence do you feel people like you have had over school integration in this county?" Responses were precoded on a fourpoint scale from "a great deal" to "none."

\section{Data Analysis}

Table 2 presents simple (Pearson) correlations between all pairs of variables for the two subsamples, and also reports multiple correlation (R's) for each of the three separate sets of predictor variables. For whites, the three simple correlations between support and desegregation policy elements (percent black enrollment, busing, distance) are the smallest in the table. Moreover, the multiple correlation coefficient for these three variables is extremely low (.176). For blacks, the distance from home to school is the only plan feature having a significant simple correlation with the dependent variable, and the multiple correlation for the three policy applications is approximately the same low figure (.182) as for whites. In both racial groups, desegregation plan elements combine to explain only slightly more than 3 percent of the variance in parents' support.

For white respondents, the highest simple correlations with support are generated by the three attitudinal variables. Support for local outputs increases with their commitment to the goals of school desegregation and belief in the legitimacy of governmental desegregation efforts, and decreases with racial prejudice. Combined, these variables explain almost 30 percent of the variance in support among white parents, far more than is attributable to perceptual variables and plan elements. ${ }^{4}$

In contrast, the overall effect of attitudes on blacks' views appears quite low. The zero-order correlation between legitimacy and support for this subsample is modest but significant (.179). However, the correlation between blacks' scores on the school integration scale and their output support (.084) barely reaches significance at the .05 level, perhaps due in part to the attenuation

analysis of variations in parents' perceptions of leaders' positions.

${ }^{4}$ Upon excluding the racial prejudice scale, the explained variance for white respondents is reduced to approximately 22 percent. This figure may be more realistically compared to the explained variance for black respondents, since the prejudice scale was not applicable to them. of blacks' scores on the scale. ${ }^{5}$ It follows that erated by these two variables $(R=.443)$ is higher than that produced by the other two sets of predictors. The multiple correlations imply that whites' support is less strongly affected by the two perceptual variables than is the case for blacks. Still, they account for about 12 percent of the variance $\left(R^{2}=.116\right)$ in whites' views of the local handling of desegregation. Also, the the total explained variance from the attitudinal variables is low $\left(\mathrm{R}^{2}=.034\right)$ for the black subsample.

The sense of efficacy and beliefs about school officials' attitudes toward integration produce the highest simple correlations with policy support among black parents. Also, for blacks the multiple correlation coefficient gentwo perceptual factors produced highly significant multiple correlations (beyond the .001 level) for both subsamples.

In sum, Table 2 suggests that even if it were possible to reduce the objective costs placed on children by the local desegregation policy, little improvement in their parents' approval of the handling of desegregation would follow. The analysis so far implies that policy support is far more contingent on parents' diffuse attitudes and their perceptions of political conditions within their districts. However, Table 2 indicates some substantial intercorrelations between independent variables both among the three theoretical categories and within them. We turn to multiple correlation and regression for all independent variables simultaneously to provide more rigorous tests of the individual hypotheses and to shed further light on the three theoretical approaches.

Main Effects. Table 3 reports the main effects of all independent variables on parents' support in each subsample. We will deal primarily with the standardized regression coefficients (betas) indicating the effect of each independent variable controlling for all the others. For white respondents, Table 3 again attests to the major importance of basic attitudes for policy support. The highest beta coefficients for whites stem from accordance with the goals of integration (.287) and with the right of government to act in the field $(.218)$. Perhaps surprisingly, racial prejudice does not appear to be directly related to white parents' policy support once the effects of the other independent variables

${ }^{5}$ The school integration scale has limits of 3 and 21. For blacks, that mean score is 19.3 with a standard deviation of 2.8. Thus, the distribution of blacks' scores is somewhat leptokurtic. The mean score for whites is $\mathbf{1 2 . 7}$ with a standard deviation of 5.6. 
are controlled. Indirectly, however, prejudice does affect whites' acceptance of local desegregation through its influence on their attitudes toward the social goals of integration and toward the right of government to enter the field. Yet even with the effects of prejudice taken into account, the sense of legitimacy and attitudes toward school integration remain important sources of white parents' acceptance of specific desegregation outputs. 6

Black parents' predispositions toward the legitimacy of governmental action are substantial contributions to their approval of the local

${ }^{6} \mathrm{~A}$ further regression, not reported here, deleted the prejudice scale but retained all other independent variables. The result was to decrease the beta coefficient for whites on the school integration scale fo .313 , while the betas for all the remaining variables, as well as the total explained variance, remained virtually identical to those reported in Table 3. handling of desegregation (beta $=.201$ ), but their scores on the school integration scale fail to produce a statistically significant beta coefficient. The latter finding is almost surely due in some measure to the limited variation in black parents' scores of the school integration scale. Because black respondents' commitment to the cause of school integration is so high and so nearly uniform, we cannot safely attribute any of the variance in their policy support to this factor. Therefore, the low multiple correlation in Table 2 between the attitudinal scales and policy support among blacks is probably not a reflection of any inherent weakness in the attitudinal approach per se.

Turning to the perceptual factors, Table 3 indicates that the sense of efficacy in influencing school desegregation decisions contributes significantly to policy support in both subsamples. The statistical findings for both whites and blacks lend credence to the hypothesis inferred from the participatory theory of democra-

Table 2. Simple (Pearson) Correlations for All Pairs of Variables, and Multiple Correlation Coefficients for Theoretical Categories of Variables

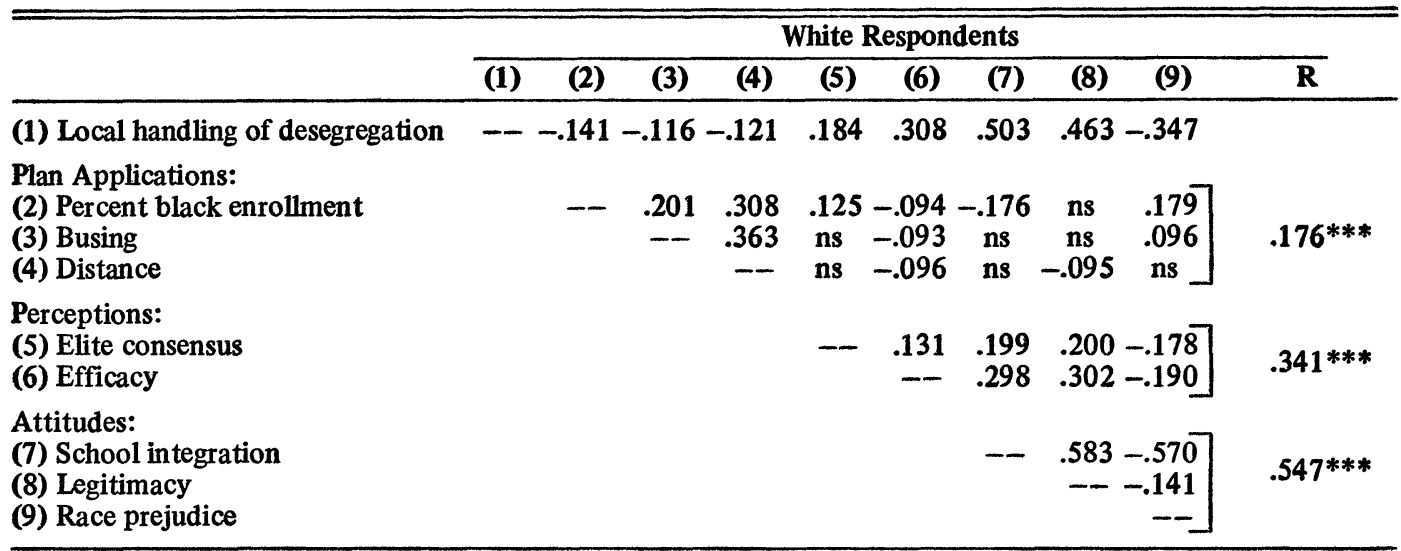

\begin{tabular}{|c|c|c|c|c|c|c|c|c|c|}
\hline & \multicolumn{9}{|c|}{ Black Respondents } \\
\hline & (1) & (2) & (3) & (4) & (5) & (6) & (7) & (8) & $\overline{\mathbf{R}}$ \\
\hline (1) Local handling of desegregation & -- & ns & ns & -.170 & .398 & .250 & .084 & .179 & \\
\hline $\begin{array}{l}\text { Plan Applications: } \\
\text { (2) Percent black enrollment } \\
\text { (3) Busing } \\
\text { (4) Distance }\end{array}$ & & - & $\stackrel{\text { ns }}{--}$ & $\begin{array}{c}\text { ns } \\
.358 \\
--\end{array}$ & $\begin{array}{r}\text { ns } \\
\text { ns } \\
-.085\end{array}$ & $\begin{array}{l}\text { ns } \\
\text { ns } \\
\text { ns }\end{array}$ & $\begin{array}{l}\text { ns } \\
\text { ns } \\
\text { ns }\end{array}$ & $\left.\begin{array}{c}\mathrm{ns} \\
\mathrm{ns} \\
.090\end{array}\right]$ & $.182 *$ \\
\hline $\begin{array}{l}\text { Perceptions: } \\
\text { (5) Elite consensus } \\
\text { (6) Efficacy }\end{array}$ & & & & & -- & .143 & $\begin{array}{l}\text { ns } \\
\text { ns }\end{array}$ & $\left.\begin{array}{l}\text { ns } \\
\text { ns }\end{array}\right]$ & $.443 * * *$ \\
\hline $\begin{array}{l}\text { Attitudes: } \\
\text { (7) School integration } \\
\text { (8) Legitimacy }\end{array}$ & & & & & & & -- & $.214]$ & $.184 * *$ \\
\hline
\end{tabular}

$$
\text { Significance (F-test): } \begin{aligned}
* & =.05 \\
* * & =.01 \\
* * * & =.001
\end{aligned}
$$


cy-that the sense of having a voice in the making of a public policy is a strong incentive to support for it.

However, there is little evidence in our data of the "follower mentality" predicated by elitist theory. Most of our respondents in 1973 had ignored, forgotten, or misconstrued Richard Nixon's anti-integrationist stance in 1972. For 70 percent of the whites and 31 percent of the blacks perceived "the president" as favoring school integration, 14 percent of the whites and 30 percent of the blacks saw him as against integration and the remainder reported not knowing his position. Further, past research (Lane and Whitney, 1973, pp. 8-10) indicates that people often project their own views upon political leaders. To the extent that projection occurs, leaders cannot be said to exert genuine influence on mass opinions. Many whites in our sample appear to have projected their attitudes toward school integration on the president, for the simple correlation between the two variables was modest but significant $(\mathrm{r}=.113)$. Further, the beta coefficient for perceptions of the president was nonsignificant for whites. For blacks, the corresponding beta was significant. However, blacks' attenuation on the school integration scale precluded a test of the projection hypothesis. The safest assumption is that basic psychological processes operate similarly in both groups. It seems unlikely, then, that blacks were any more open to influence from the president than were whites.
The evidence is not much more impressive respecting local school officials' influence on parents' support. As was the case regarding the president, whites frequently appear to project their predispositions upon local school officials, for Table 2 reports significant simple correlations between whites' scores on the school integration, legitimacy, and race prejudice scales and their perceptions of district officials' positions. Still, controlling for whites' attitudes, their perceptions of local officials make a significant yet extremely slight contribution (.061) to the total variance in their support. ${ }^{7}$

For blacks, perceptions of school officials' views toward school integration produce the strongest beta coefficient in the equation (.377). Nevertheless, it is hard to accept the

\begin{abstract}
${ }^{7}$ For whites, the projection hypothesis was tested more rigorously by examining the difference in explained variance between a restricted regression model, including all independent variables except perceptions of officials' positions, with a full model incorporating the perceptual factor and all other independent variables. Since the restricted model permits attitudinal forces to make their fullest contributions to the explained variance, any additional variance explained by the full model can be attributed to the unique influence of perceptions of officials. This test revealed that for whites, the full model produced an explained variance of only .037 in excess of that from the restricted model, although this difference was unlikely to be due to chance. For a fuller explication of this procedure, see Wright (1976).
\end{abstract}

Table 3. Multiple Correlation and Regression Analysis of Support for Desegregation Policy

\begin{tabular}{|c|c|c|c|c|c|c|c|}
\hline & \multicolumn{3}{|c|}{ White Respondents } & \multicolumn{4}{|c|}{ Black Respondents } \\
\hline & (b) (beta) & (s) & (F) & (b) & (beta) & (s) & (F) \\
\hline $\begin{array}{l}\text { Independent Variables: } \\
\text { Percent black enrollment } \\
\text { Busing } \\
\text { Distance bused } \\
\text { School integration scale } \\
\text { Legitimacy scale } \\
\text { Race prejudice scale } \\
\text { Perceptions of local elites } \\
\text { Perceptions of efficacy }\end{array}$ & $\begin{array}{rr}-.106 & -.040 \\
-.123 & -.051 \\
-.094 & -.032 \\
.049 & .287 \\
.041 & .218 \\
.009 & .044 \\
.098 & .061 \\
.108 & .128\end{array}$ & $\begin{array}{l}.068 \\
.063 \\
.078 \\
.006 \\
.006 \\
.006 \\
.040 \\
.036\end{array}$ & $\begin{array}{l}2.416 \\
3.845^{*} \\
1.477 \\
73.728^{* * *} \\
51.974^{* * *} \\
2.201 \\
5.945^{*} \\
24.984^{* * *}\end{array}$ & $\begin{array}{r}-.008 \\
.018 \\
-.510 \\
.210 \\
.040 \\
-.0 \\
.492 \\
.224\end{array}$ & $\begin{array}{r}-.059 \\
.007 \\
-.153 \\
.056 \\
.201 \\
. \overline{377} \\
.185\end{array}$ & $\begin{array}{l}.004 \\
.091 \\
.129 \\
.014 \\
.007 \\
.048 \\
.044\end{array}$ & $\begin{array}{c}2.720 \\
.041 \\
15.686 * * * \\
2.315 \\
29.591^{* * *} \\
-\overline{107.404 * * *} \\
25.820^{* * *}\end{array}$ \\
\hline $\begin{array}{l}\text { Dependent Variable } \\
\quad \text { Mean (5-point scale) } \\
\text { Standard deviation } \\
\text { F-ratio } \\
\text { Standard error of estimate } \\
\text { Number of respondents } \\
\mathbf{R} \\
\mathbf{R}^{2}\end{array}$ & $\begin{array}{r}2.290 \\
1.218 \\
71.393 \\
.990 \\
1184 \\
.572 \\
.327\end{array}$ & & & $\begin{array}{r}3.315 \\
1.172 \\
29.639 \\
1.013 \\
581 \\
.516 \\
.266\end{array}$ & & & \\
\hline
\end{tabular}

F-test:

$$
\begin{aligned}
* * * p & <.001 \\
* * p & <.01 \\
* p & <.05
\end{aligned}
$$


notion that, after generations of discrimination, blacks have become susceptible to influence from the predominantly white school officials in our study districts. The strong beta may have other sources. ${ }^{8}$ It might be supposed that blacks whose children bear a heavy objective burden from the desegregation plan feel that local decision makers were hostile to racial integration. This assumption would be consistent with the significant negative correlation for blacks (Table 2) between busing distance and perceptions of district officials. And, as noted previously, increasing distances tend to depress blacks' approval of the handling of desegregation in their districts. Hence, notwithstanding the statistical evidence in Table 3 , it remains questionable whether black parents' support for local policies was molded by their school district officials.

White and black parents appear to react somewhat differently to the three objective policy elements. For neither subsample does the black/white attendance ratio in the child's school produce a significant beta coefficient. Busing per se has a slightly negative effect on whites' but not on blacks' approval of local outputs. Among blacks whose children are bused, however, an increasing distance appears to depress policy support. We turn to a closer examination of these policy impacts below.

Interaction Effects. The impacts of objective policy elements are not fully tested by the regression model used so far, for it estimates only the individual additive effects of variables. However, the plan elements are applied to many children in combinations. Thus, while a high percent black enrollment seems to have little influence on support, it may become more important when it occurs together with busing and a long distance from home to school. Therefore, a series of variables was constructed to specify all second- and third-order interactions among the three plan elements, and were added to the main effects regression model presented in Table 3.9

For whites, none of the interaction terms produced a statistically significant beta coef-

\footnotetext{
${ }^{8}$ Perhaps the very fact that desegregation had taken place in our study districts made some black parents presume that local officials favored school integration. The hypothesis could not be tested since our sample does not include blacks in districts that have not been desegregated. However, even if the hypothesis were validated, it would not necessarily mean that blacks' perceptions of officials determined their support for district outputs.

${ }^{9}$ Interaction terms were obtained by multiplying the appropriate policy variables.
}

ficient. That is, over and above busing per se, a longer bus ride or an assignment to a heavily black school, or both, have no further depressing effects on whites' support. Hence, the conclusion from Table 3 is reconfirmed-that busing as such is the dominant policy application influencing white parents' policy support.

For blacks, however, clear and strong evidence of policy influence on support emerges from the inclusion of the interaction terms. Preliminary analysis (not reported) revealed that one such term, representing the simultaneous application of all three plan elements, was statistically significant for blacks. Table 4 presents the final regression solution for these parents including the significant interaction. The third-order interaction term is presented conditionally with the effects of the percent black enrollment examined within categories of busing and distance. ${ }^{10}$ Table 4 shows that among blacks whose children are bused a long distance, an increase in the percent black enrollment strongly diminishes support (beta $=$ -.335). However, increases in the percent black have no effect among those bused a short distance. ${ }^{11}$ Moreover, with the combined effect of busing and percent black specified, the main effect of the distance bused is reduced to statistical insignificance. Apparently, then, the linkage between distance and policy support in Table 3 stemmed from low support among black parents whose children were bused a long distance to schools with higher percentages of black pupils.

Why does the support of blacks decline so precipitously when their children are bused a long way to heavily black schools but not to heavily white schools, and why is their support unaffected by a shorter bus ride to a school with many black children? Upon reflection, these findings are not surprising. For the black children in question are not only bused, but also they must travel a long distance, only to disembark at schools very similar in racial composition to those in the neighborhoods where they boarded the bus. To school district planners, this combination of policy elements may seem warranted as part of a rational strategy for achieving a federally acceptable distribution of black and white children among local schools. To black parents, however, this pattern may well appear both burdensome and pointless.

${ }^{10}$ That is, the percent black enrollment is allowed to vary within the fixed categories of distance among bused children.

${ }^{11}$ Similarly, the lack of significant interactions indicates that all other combinations of policy impacts are also nonsignificant. 
Altogether, the regression analyses have accounted for about one-third of the variance of whites' support and approximately one-fourth of the variance in blacks' support. These figures may seem respectably high given that the analysis has been restricted primarily to hypotheses drawn from empirical political theory. Perhaps the addition of some sociological or demographic variables might inflate the multiple correlation coefficients. In any case, the research goal has not been to maximize overall predictive power but rather to assess the relative utility of several political science approaches to explaining policy support in a target group.

\section{Discussion}

We began by setting forth three theoretical approaches to explaining specific support for a governmental policy among its target group members. The first suggests that support will vary with the objective costs and benefits of the policy. The other two approaches focus upon subjective factors-diffuse attitudes and perceptions of the policy-making process-as determinants of support. Our analyses leave a deep impression of the weakness of the costbenefit approach and the strength of subjective factors in explaining both black and white parents' support for school desegregation outputs in their communities.

The cost-benefit assumption is firmly grounded in utility theories of individual be- havior current in political science and economics. Furthermore, policy makers themselves appear to believe that the objective demands of policies will affect a target group's reactions and try to anticipate "what the market will bear" in formulating outputs. In this light, our most intriguing finding is a negative one-that the objective demands placed upon school children by desegregation have, at most, only very slight impact on parental support for local policies. Busing is the only policy element that depresses whites' support, while only the most extreme combination of all three elements diminishes blacks' support. Nevertheless, these policy demands pale in causal importance when compared to the effects of subjective attitudes and perceptions of parents' acceptance of the handling of desegregation in their school districts. Our findings underscore Edelman's contention (1960, passim) that the costs and benefits of a policy may be more symbolic than tangible.

It is hardly surprising to find that increasingly favorable attitudes toward the goals of school integration generate increasing approval of district desegregation policies. However, target group support is not simply a function of agreement with the general purposes of the policy. It is also rooted in parents' appraisal of two political objects. First, our analyses corroborate recent theory and research indicating that a diffuse sense of the legitimacy of governmental action in a policy field stimulates specific support for related outputs. Second,

Table 4. Black Respondents: Interaction Effects of Desegregation Plan Applications

\begin{tabular}{|c|c|c|c|c|}
\hline & (b) & (beta) & (s) & (F) \\
\hline \multicolumn{5}{|l|}{ Independent variables: } \\
\hline Perceptions of local officials & .497 & .381 & .047 & $110.85 * * *$ \\
\hline Legitimacy scale & .040 & .204 & .007 & $30.93 * * *$ \\
\hline Perceptions of efficacy & .225 & .185 & .044 & $26.30 * * *$ \\
\hline \multicolumn{5}{|l|}{ Bused, long distance, and percent } \\
\hline black enrollment & -.688 & -.335 & .221 & $9.73 * *$ \\
\hline \multicolumn{5}{|l|}{ Bused, short distance, and } \\
\hline percent black enrollment & -.007 & -.057 & .005 & 2.51 \\
\hline School integration scale & .021 & .056 & .014 & 2.33 \\
\hline Distance bused & .528 & .158 & .360 & 2.15 \\
\hline Busing & -.033 & -.014 & .090 & .13 \\
\hline \multicolumn{5}{|l|}{ Multiple correlation: } \\
\hline F-ratio & 27.509 & & & \\
\hline Standard error of estimate & 1.001 & & & \\
\hline Number of respondents & 580 & & & \\
\hline R & .527 & & & \\
\hline $\mathbf{R}^{2}$ & .278 & & & \\
\hline
\end{tabular}

F-test:

$$
\begin{gathered}
* * * \mathrm{p}<.001 \\
* * \mathrm{p}<.01 \\
*_{\mathrm{p}}<.05
\end{gathered}
$$


participatory theories of democracy stress the value that citizens may attach to their ability to make effective contributions to the making of policies directly affecting them, and our data bear out this assumption. Parents' beliefs about their efficacy in influencing desegregation policy making in their districts were a strong contributor to their support. Diffuse predispositions aside, specific support is unlikely to be maximized when the decision-making process is widely viewed as insulated from citizen influence.

However, by the most generous interpretation, our analyses lend only tenuous confirmation to the elitist assumption that public officials shape the target group's reactions to desegregation policies. There was no convincing relationship between parents' perceptions of the president's position on the integration issue and their acceptance of local policies. Moreover, contrary to much of the topical literature, local school officials seem generally unable to induce a recalcitrant white public to accept desegregation. Whites' perceptions of district officials' attitudes toward school integration often seemed to be simply projections of their own views. Once these projection effects were taken into account, the perceived position of local school officials had only trace effects on whites' support.

At first glance, blacks' perceptions of district officials' positions on the integration issue appeared to be a strong statistical predictor of their policy support, and there was no evidence that blacks projected their general enthusiasm for school integration upon local officials. Nevertheless, some of the data implied that blacks' satisfaction with district policies may be a determinant of their perceptions of officials, rather than vice versa as the elitist hypothesis holds. Therefore, it remains doubtful that blacks are any more open to elite influence than are whites.

These conclusions are parallel to Hamilton's finding (1970) that political and social elites were unable to arouse mass support for open housing measures, and at odds with Mueller's finding $(1973$, pp. $69-73,123)$ that the mass public normally has played a follower role vis-à-vis the president on foreign policy issues. Thus, elite influence may vary according to the issue. School desegregation, like open housing, directly affects the everyday lives of target group members and engages long-standing attitudinal commitments concerning race relations. Given these conditions, the individual probably has a sufficient personal framework for assessing policies without resorting to cues from elites. On the other hand, when issue objects are more remote (e.g., foreign policy) or when fundamental values are not threatened, the assumption of elite influence may yet hold true.

Black and white respondents have been analyzed separately because it was initially supposed that the sources of support might be different for the two groups. However, this does not appear to be so. Some seeming differences between blacks and whites were almost surely due to technical difficulties in measuring black parents' attitudes (i.e., the lack of a valid scale of blacks' stereotypes of whites and the attenuation of blacks' scores on the school integration scale). Hence, policy makers probably face much the same kinds of problems in stimulating support for desegregation in both racial groups.

It is hard to be optimistic about the prospects for improving whites' views of desegregation policies, at least in the short run. For our analyses portray a target group whose policy support is largely rooted in fundamental attitudes which probably change slowly. There is virtually no evidence in these data that district officials can increase support either by minimizing the objective costs of desegregation to parents or by presenting a united front in favor of school integration. Only an "interactive" leadership strategy appears to hold much promise-i.e., one that facilitates citizen contributions to district policy making, that accommodates citizens' wants to realistic policy alternatives, and that reduces the social distance between target group members and policy makers. The data imply that strategies of this nature might generate a somewhat broader acceptance of local desegregation outputs. Their costs may be far less than the costs of continued public nonsupport, the ramifications of which were suggested in the beginning of this study.

\section{References}

Almond, Gabriel A., and Sidney Verba (1963). The Civic Culture: Political Attitudes and Democracy in Five Nations. Princeton: Princeton University Press.

Beckler, John (1971). "Has School Integration in the South Gone as Far as It Can Go?" School Management 15:2.

Chesler, Mark A., Judith Guskin and Phyllis Erenburg (1969). Planning Educational Change; Vol. 2: Human Resources in School Desegregation. Washington: U.S. Government Printing Office.

Coleman, James S., et al. (1966). Equality of Educational Opportunity. Washington: U.S. Government Printing Office.

Congressional Quarterly Almanac (1972). Washington: Congressional Quarterly. 
Crain, Robert L., et al. (1974). Design for a National Longitudinal Study of School Desegregation; Vol. 1, Issues in Theory and Method. Santa Monica, Calif.: Rand.

Robert A. Dahl (1961). Who Governs? Democracy and Power in an American City. New Haven: Yale University Press.

Dennis, Jack (1973). Socialization to Politics. New York: Wiley.

Downs, Anthony (1957). An Economic Theory of Democracy. New York: Harper.

Dye, Thomas R., and L. Harmon Zeigler (1970). The Irony of Democracy. Belmont, Calif.: Wadsworth.

Easton, David (1965). A Systems Analysis of Political Life. New York: Wiley.

Edelman, Murray (1960). "Symbols and Political Quiescence." American Political Science Review 54:695-704.

Farley, Reynolds, and Alma F. Taeuber (1974). "Racial Segregation in the Public Schools." American Journal of Sociology 79:888-905.

Gallup Opinion Index (1973). Princeton: Gallup Opinion Index, October, 1973, Report No. 100, 14.

Giles, Micheal W. (1975). "Black Concentration and School District Size as Predictors of School Segregation: The Impact of Federal Enforcement." Sociology of Education 48:411-19.

_ Douglas S. Gatlin and Everett F. Cataldo (1976). "Parental Support for School Referenda." Journal of Politics 38:442-51.

Graglia, Lino A. (1976). Disaster by Decree. Ithaca, N.Y.: Cornell University Press.

Greeley, Andrew M., and Paul B. Sheatsley (1971). "Attitudes Toward Racial Integration." Scientific American 225:13-19.

Hamilton, Howard D. (1970). "Direct Legislation: Some Implications of Open Housing Referenda." American Political Science Review 64:124-37.

Johnson, Richard M. (1967). The Dynamics of Compliance: Supreme Court Decision-Making From a New Perspective. Evanston, Ill.: Northwestern University Press.

Kelley, Jonathan (1974). "The Politics of School Busing." Public Opinion Quarterly 38:23-39.
Knapp, Melvin J., and Jon P. Alston (1972-73). "White Parental Acceptance of Varying Degrees of School Desegregation: 1965 and 1970." Public Opinion Quarterly 38:585-91.

Lane, Robert E., and David O. Sears (1964). Public Opinion. Englewood Cliffs, N.J.: Prentice-Hall.

Lane, Robert E., and Richard E. Whitney (1973). Political Persuasion. Morristown, N.J.: General Learning Press.

Miller, Arthur M., and Jack Citrin (1974). "Political Issues and Trust in Government: 1964-1970." American Political Science Review 68:951-72.

Mueller, John E. (1973). War, Presidents and Public Opinion. New York: Wiley.

Nevin, David, and Robert E. Bills (1976). The Schools that Fear Built. Washington: Acropolis.

Pateman, Carole (1970). Participation and Democratic Theory. New York: Cambridge University Press.

Pettigrew, Thomas F. (1971). Racially Separate or Together? New York: McGraw-Hill.

Rourke, Francis E. (1976). Bureaucracy, Politics, and Public Policy. 2nd ed. Boston: Little, Brown.

Salem, Richard G., and William J. Bowers (1972). "Severity of Formal Sanctions as a Deterrent to Deviant Behavior." In Samuel Krislov, et al. (eds.), Compliance and the Law, pp. 313-32. Beverly Hills, Calif.: Sage.

St. John, Nancy H. (1975). School Desegregation: Outcomes for Children. New York: Wiley.

Stover, Robert V., and Don W. Brown (1975). "Understanding Compliance and Non-Compliance with Law: The Contributions of Utility Theory." Social Science Quarterly 56:363-75.

Thompson, Dennis F. (1970). The Democratic Citizen: Social Science and Democratic Theory in the Twentieth Century. London: Cambridge University Press.

Tumin, Melvin, Paul Barton, and Bernie Burrus (1958). "Education, Prejudice and Discrimination: A Study in Readiness for Desegregation." American Sociological Review 23:41-49.

Wright, Gerald C., Jr. (1976). "Linear Models for Evaluating Conditional Relationships." American Journal of Political Science 20:349-73. 